\title{
Calcium carbonate saturation in the surface water of the Arctic Ocean: undersaturation in freshwater influenced shelves
}

\author{
M. Chierici ${ }^{1}$ and A. Fransson ${ }^{2}$ \\ ${ }^{1}$ University of Gothenburg, Department of Chemistry, Marine Chemistry, 41296 Göteborg, Sweden \\ ${ }^{2}$ University of Gothenburg, Department of Earth Sciences, Oceanography, 40350 Göteborg, Sweden
}

Received: 16 April 2009 - Published in Biogeosciences Discuss.: 13 May 2009

Revised: 11 September 2009 - Accepted: 24 October 2009 - Published: 4 November 2009

\begin{abstract}
In the summer of 2005, we sampled surface water and measured $\mathrm{pH}$ and total alkalinity $\left(\mathrm{A}_{\mathrm{T}}\right)$ underway aboard IB Oden along the Northwest Passage from Cape Farewell (South Greenland) to the Chukchi Sea. We investigated the variability of carbonate system parameters, focusing particularly on carbonate concentration $\left[\mathrm{CO}_{3}^{2-}\right]$ and calcium carbonate saturation states, as related to freshwater addition, biological processes and physical upwelling. Measurements on $\mathrm{A}_{\mathrm{T}}, \mathrm{pH}$ at $15^{\circ} \mathrm{C}$, salinity ( $\mathrm{S}$ ) and sea surface temperature (SST), were used to calculate total dissolved inorganic carbon $\left(\mathrm{C}_{\mathrm{T}}\right),\left[\mathrm{CO}_{3}^{2-}\right]$ and the saturation of aragonite $(\Omega \mathrm{Ar})$ and calcite $(\Omega \mathrm{Ca})$ in the surface water. The same parameters were measured in the water column of the Bering Strait. Some surface waters in the Canadian Arctic Archipelago (CAA) and on the Mackenzie shelf (MS) were found to be undersaturated with respect to aragonite $(\Omega \mathrm{Ar}<1)$. In these areas, surface water was low in $A_{T}$ and $\mathrm{C}_{\mathrm{T}}\left(<1500 \mu \mathrm{mol} \mathrm{kg}^{-1}\right)$ relative to seawater and showed low $\left[\mathrm{CO}_{3}^{2-}\right]$. The low saturation states were probably due to the likely the effect of dilution due to freshwater addition by sea ice melt (CAA) and river runoff (MS). High $\mathrm{A}_{T}$ and $\mathrm{C}_{\mathrm{T}}$ and low $\mathrm{pH}$, corresponded with the lowest $\left[\mathrm{CO}_{3}^{2-}\right]$, $\Omega \mathrm{Ar}$ and $\Omega \mathrm{Ca}$, observed near Cape Bathurst and along the South Chukchi Peninsula. This was linked to the physical upwelling of subsurface water with elevated $\mathrm{CO}_{2}$. The highest surface $\Omega \mathrm{Ar}$ and $\Omega \mathrm{Ca}$ of 3.0 and 4.5 , respectively, were found on the Chukchi Sea shelf and in the cold water north of Wrangel Island, which is heavily influenced by high $\mathrm{CO}_{2}$ drawdown and lower $\mathrm{C}_{\mathrm{T}}$ from intense biological production. In the western Bering Strait, the cold and saline Anadyr Current carries water that is enriched in $\mathrm{A}_{T}$ and $\mathrm{C}_{T}$ from enhanced organic matter remineralization, resulting in the lowest $\Omega \operatorname{Ar}(\sim 1.2)$ of the area.
\end{abstract}

Correspondence to: $\mathrm{M}$. Chierici

(melissa@chem.gu.se)

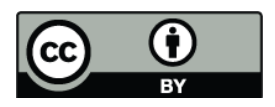

\section{Introduction}

The gradual $\mathrm{CO}_{2}$ increase in the ocean due to the uptake of anthropogenic $\mathrm{CO}_{2}$ is of major concern, due to the changes in the oceanic $\mathrm{CO}_{2}$ system and the effect on marine life (Raven et al., 2005). The matter of ocean acidification caused by the $\mathrm{CO}_{2}$ uptake was discussed as early as in the 1970's (e.g. Skirrow and Whitfield, 1975; Broecker and Takahashi, 1977), and has gained increased attention during the 21 st century. In itself, $\mathrm{CO}_{2}$ is an "acidic" molecule, because the dissolved $\mathrm{CO}_{2}$ gas reacts with water to form carbonic acid $\left(\mathrm{H}_{2} \mathrm{CO}_{3}\right.$, Eq. 1). Increased oceanic uptake of $\mathrm{CO}_{2}$ has led to decreases in ocean $\mathrm{pH}$ and carbonate ion concentration $\left(\left[\mathrm{CO}_{3}^{2-}\right]\right)$. Since the industrial revolution, the surface ocean $\mathrm{pH}$ has dropped by 0.1 units (Caldeira and Wickett, 2003) and is projected to drop another 0.3 ito 0.4 units by 2100 (Feely et al., 2004; Orr et al., 2005). The increase of anthropogenic $\mathrm{CO}_{2}$ has led to the shallower carbonate saturation horizon of several hundred of meters in the Japan Sea (Park et al., 2006). Several laboratory studies have shown that reduction in levels of $\mathrm{CaCO}_{3}$ saturation reduces calcification in marine calcifiers, such as calcifying phytoplankton (e.g. Riebesell et al., 2000) and coral reefs (Gattuso et al., 1998). However, the complexity of the marine biogeochemical processes and the lack of the complete knowledge of the effect on oceanic $\mathrm{CO}_{2}$ chemistry have led to difficulties in predicting the consequences for marine life. It has also been difficult to set the appropriate threshold levels for a tolerable $\mathrm{pH}$ change (Zeebe et al., 2008). For the complete understanding of the effects of acidification, we need to assess all the aspects of the forcing of the marine $\mathrm{CO}_{2}$ system. Model results have shown that the high latitude oceans will be the first to become undersaturated with respect to calcite and aragonite (Orr et al., 2005).

\author{
(melissa@chem.gu.se)
}

Published by Copernicus Publications on behalf of the European Geosciences Union. 


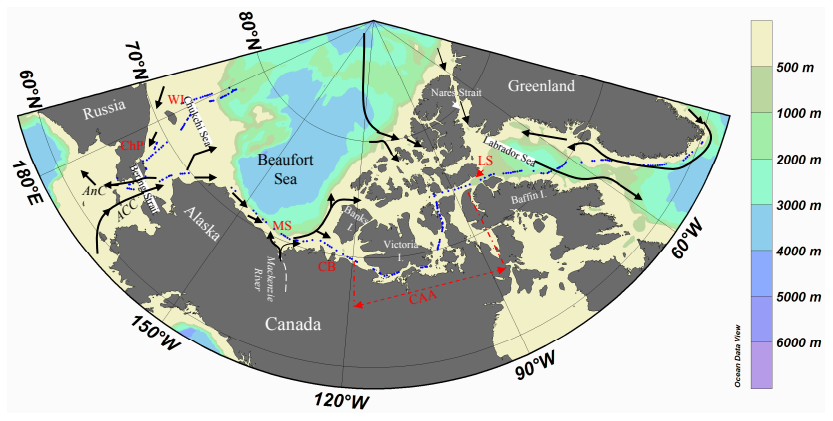

Fig. 1. Location of the 242 water samples taken onboard the $I B$ Oden during summer 2005 (blue dots). The seven CTD-rosette stations in the Bering Strait are indicated individually in Figs. 3, 10, and 11. The black arrows indicate the major surface currents (e.g. Rudels et al., 2004; Weingartner et al., 2005). The ACC denotes the Alaskan Coastal Current and $\mathrm{AnC}=$ Anadyr Current. In red, MS denotes Mackenzie shelf, $\mathrm{CB}=\mathrm{Cape}$ Bathurst, $\mathrm{ChP}=$ Chukchi Peninsula, WI=Wrangel Island. The approximate area of the Canadian Arctic Archipelago (red, CAA, $84^{\circ} \mathrm{W}$ to $120^{\circ} \mathrm{W}$ ) is marked with red dashed lines. The colour scale bar illustrates the depth contours in meter.

The carbonate saturation $(\Omega)$ does not only depend on the $\left[\mathrm{CO}_{3}^{2-}\right]$ but also on other factors such as pressure, temperature, salinity. Ocean $\mathrm{pH}$ is affected by biological primary production and respiration, physical mixing, air-sea $\mathrm{CO}_{2} \mathrm{ex}-$ change, and ocean $\mathrm{CO}_{2}$ chemistry. The $\mathrm{CO}_{2}$ uptake during the formation of soft organic matter during photosynthesis increases the $\mathrm{pH}$ of surrounding water, whereas the respiration of organic matter releases $\mathrm{CO}_{2}$, leading to a $\mathrm{pH}$ decrease. Consequently, the balance between production and respiration and the sinking of organic matter could be a major control over the $\left[\mathrm{CO}_{3}^{2-}\right]$ saturation state in the whole water column. In the surface ocean, the biological production of hard parts, such as shells and skeletons, is the major process leading to $\mathrm{CaCO}_{3}$ formation and takes place in the upper part of the ocean. This process produces $\mathrm{CO}_{2}$ thus lowering $\mathrm{pH}$ according to Eqs. (1) and (2).

$$
\begin{aligned}
& \mathrm{CO}_{2}(\mathrm{aq})+\mathrm{H}_{2} \mathrm{O} \leftrightarrow \mathrm{H}_{2} \mathrm{CO}_{3} \leftrightarrow \mathrm{H}^{+}+\mathrm{HCO}_{3}^{-} \leftrightarrow 2 \mathrm{H}^{+}+\mathrm{CO}_{3}^{2-} \\
& 2 \mathrm{HCO}_{3}^{-}+\mathrm{Ca}^{2+} \rightarrow \mathrm{CaCO}_{3}(\mathrm{~s})+\mathrm{H}_{2} \mathrm{O}+\mathrm{CO}_{2}(\mathrm{aq})
\end{aligned}
$$

Surface waters are generally supersaturated with respect to $\mathrm{CaCO}_{3}$. However it is rare for $\mathrm{CaCO}_{3}$ to precipitate inorganically because of complex ion-ion interactions, which inhibit the $\mathrm{Ca}^{2+}$ ion. Magnesium $\left(\mathrm{Mg}^{2+}\right)$ is one of the "competing" ions that depresses a spontaneous inorganic formation of $\mathrm{CaCO}_{3}$ as expected from thermodynamics (e.g. Rushdi et al., 1992). Thus it is through biological processes that $\mathrm{CaCO}_{3}(\mathrm{~s})$ is formed in the ocean. Aragonite (Ar) and calcite (Ca) are the two most common forms of $\mathrm{CaCO}_{3}$ found in the ocean, with aragonite being the metastable form and calcite the stable form. Recently, there has been the report of undersaturation with respect to aragonite in the surface waters off the Oregon-California coast. This undersaturation was attributed to the natural upwelling of $\mathrm{CO}_{2}$-rich subsurface waters in combination with increased ocean $\mathrm{CO}_{2}$ concentrations from the uptake of anthropogenic $\mathrm{CO}_{2}$ (Feely et al., 2008). Cold and fresh water promotes lower $\mathrm{CaCO}_{3}$ saturation states (Mucci et al., 1983). For example, the Baltic Sea is a brackish and relatively cold enclosed ocean, which has naturally low $\mathrm{pH}$ values and low carbonate saturation states in winter (Tyrrell et al., 2008). Yet, the Black Sea, another brackish water system, is strongly supersaturated year-round and has the presence of the calcifying phytoplankton Emiliania huxleyi. Tyrrell et al. (2008) suggest that the difference between these two brackish water systems may be due to differences in salinity or silicate concentration (Tyrrell et al., 2008). The combined effect of cold and relatively fresh water, and the highly biologically productive shelf seas, makes the Arctic Ocean one of the more sensitive areas for the continuing uptake of anthropogenic $\mathrm{CO}_{2}$. Jutterström and Anderson (2005) investigated the carbonate saturation and the saturation horizon in the deeper ocean basins of the Arctic Ocean. They found that the saturation horizons of calcite $(\Omega \mathrm{Ca}=1)$ and aragonite $(\Omega \mathrm{Ar}=1)$ in the Arctic Ocean were located at approximately $4000 \mathrm{~m}$ and $2500 \mathrm{~m}$, respectively.

In this study, we focus on the variability of the carbonate system in the coastal environment of the Arctic Ocean. We use measured total alkalinity, $\mathrm{pH}$, salinity and temperature, collected by underway sampling on the cruise track along the Northwest Passage, from South Greenland to the Bering and the Chukchi seas in the summer of 2005. We also present the cross section of these parameters obtained from water column sampling in the Bering Strait. Based on chemical equilibrium equations and sea surface salinity $(S)$ and temperature (SST), we calculated the concentrations of the carbonate ion $\left(\left[\mathrm{CO}_{3}^{2-}\right]\right)$ and the calcite $(\Omega \mathrm{Ca})$ and aragonite saturation states $(\Omega \mathrm{Ar})$. The results are discussed with regard to the variability in the sea-ice cover, freshwater, and hydrography. One of our goals is to use the large natural variability of the marine carbonate system in this study area, to provide basic information needed to predict the response to future changes in the $\mathrm{CaCO}_{3}$ saturation of the upper Arctic Ocean due to changes in sea ice extent and temperature. We also provide methods to use the underway sampling of seawater to study the $\mathrm{CO}_{2}$ system and facilitate future monitoring of changes due to ocean acidification.

\section{Study area}

The IB Oden cruise track followed the Northwest Passage from Cape Farewell (South Greenland), passing through the Canadian Arctic Archipelago (CAA), the Mackenzie shelf (MS) and the Beaufort Sea shelf, the Chukchi Sea, the Bering Strait, and in the western East Siberian Sea (ESS), to the northeast of Wrangel Island, WI, (Fig. 1). In these regions, the water is modified by mixing, seasonal freezing 
and melting, river runoff and biogeochemical processes. Carmack et al. (2006) summarize the different characteristics of our study area and we have used their definitions to describe the physical state along the cruise track. Figure 1 shows the water sampling locations together and the major surface currents in the study area.

Along the transect we encountered both ice-free areas and other areas with extensive ice cover throughout the summer. Sea-ice conditions are based on observations during the cruise, ice charts and the report from the Canadian Ice Services (CISA, 2005). Also, Fransson et al. (2009) describe the ice conditions and relative fractions of sea ice melt and river runoff computed from the $\mathrm{A}_{\mathrm{T}}-\mathrm{S}$ relationship. In our study area, the CAA and the area north of Wrangel Island were ice covered, whereas open water was found on the Mackenzie shelf, in the Bering Sea and over large parts of the Chukchi Sea. The southern Beaufort Sea was mainly ice-free.

Surface water salinity and temperature varied along the ship track (Fig. 2a and b). Relatively warm $\left(\sim 4^{\circ} \mathrm{C}\right)$ and saline ( 33.9) Atlantic water enters from the south eastern part of the Labrador Sea. From the north, the fresh and cold surface water from the Arctic Ocean enters the Labrador Sea, through the channels between the islands in the CAA (Fig. 1). This water has Atlantic origin having already come through Fram Strait, and it flows out to the Labrador Sea via Nares Strait (Rudels et al., 2004). The coldest water of $-1.5^{\circ} \mathrm{C}$ was observed in the CAA, in association with sea-ice cover. South of Banks Island, we encountered open water and a dramatic temperature increase from below 0 to $6^{\circ} \mathrm{C}$, which coincided with a salinity increase from 27 to 32 . This was probably associated with wind-induced upwelling of warm, salty subsurface water around the Cape Bathurst Peninsula, where the shelf break in the Amundsen Gulf creates a polynya in spring, which recurs annually (Barber and Hanesiak, 2004). At this same location Fransson et al. (2009) found elevated fugacity of $\mathrm{CO}_{2}\left(f \mathrm{CO}_{2}\right)$ in the surface water, which indicates upwelling of $\mathrm{CO}_{2}$-rich subsurface water. During winter, the polynyas along the coast are sites of dense water production on the shelf due to enhanced brine formation as the result of dynamic sea-ice production (e.g. Shimada et al., 2005), and they are also important due to their large biological productivity (e.g. Grebmeier et al., 1988) and impact on the local carbon cycle.

The Mackenzie shelf (MS) and the nearshore southern Beaufort Sea were influenced by warm runoff from the Mackenzie River and other smaller rivers in the area. Here we observed a SST increase from about $4^{\circ} \mathrm{C}$ to $7^{\circ} \mathrm{C}$ and a drastic salinity decrease from 30 to 11.9 . The cruise continued over the shallow shelves in the Beaufort Sea and the Chukchi Sea, bounded on the south by the Bering Strait, on the west by Wrangel Island, and on the east by Barrow Canyon. The warmest water of $8.9^{\circ} \mathrm{C}$ was measured in the southern part of the Chukchi Sea, close to the Siberian coast and at the southern coast of the Chukchi Peninsula. The Chukchi Sea is strongly forced, both physically and biolog-

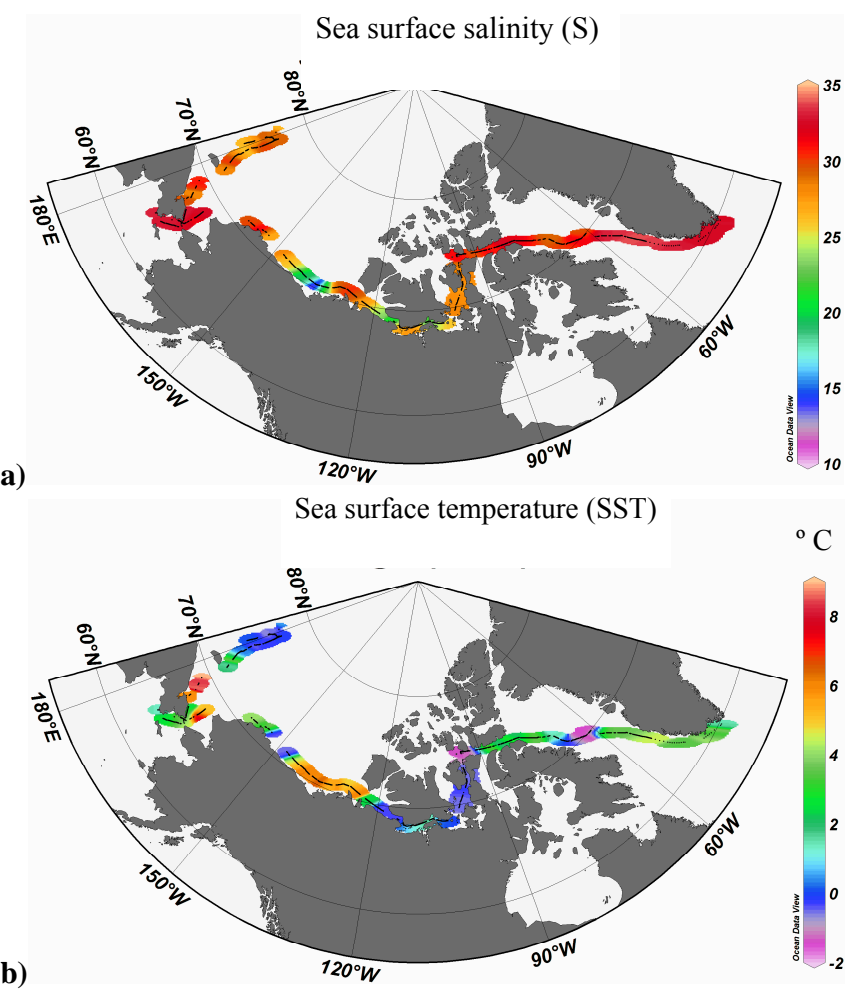

Fig. 2. The 1-minute data of (a) sea surface salinity and (b) sea surface temperature $\left(\mathrm{SST},{ }^{\circ} \mathrm{C}\right)$ along the cruise track. The color bar illustrates the scale in salinity and temperature, respectively.

ically, by the inflow of Pacific waters $(0.8 \mathrm{~Sv})$ and the warm and fresh water transported by the Alaskan Coastal Current (ACC, Fig. 1), entering through the Bering Strait (e.g. Weingartner et al., 2005). The Chukchi Sea also has seasonal ice cover that is highly variable from year to year.

The Diomede Islands divide the Bering Strait into two channels. The cross section of temperature (T) and salinity (S) of the Bering Strait reveals the cold and saline water in the western channel (Fig. 3a and b), that originates from the Anadyr Current (AnC, Fig. 1) from the south. On the eastern side (the Alaskan side), the ACC brings warm and fresh water, influenced by the Alaskan rivers, which flows into the Arctic Ocean through the Bering Strait (Woodgate and Aagaard, 2005).

\section{Data and methods}

The IB Oden expedition took place from the 12 July to 16 August 2005. Surface sea water was pumped to the main laboratory through stainless steel tubing from the ship's water intake, located at the bow at the depth of about $8 \mathrm{~m}$. We collected discrete surface-water samples when the ship was in transit when ice conditions did not prevent sampling from the seawater intake. However, there was no sampling during 8 days, when the ship was awaiting other scientific 


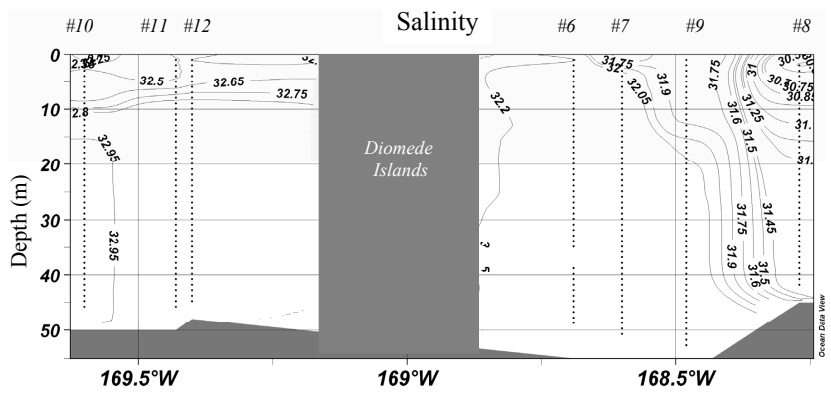

(a)

W. Bering Strait

E. Bering Strait

Temperature $\left({ }^{\circ} \mathrm{C}\right)$

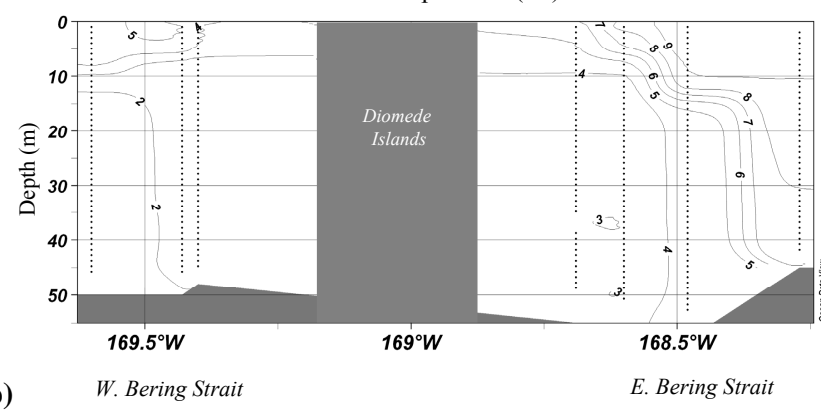

Fig. 3. A cross section of salinity and temperature $\left({ }^{\circ} \mathrm{C}\right)$ in the Bering Strait from the seven water column stations (\#6 to \#12, for positions see Table 1). The Diomede Islands separate the strait into two channels.

missions and during exchange of scientists, when the ship was in Barrow (2 days). Also, no samples were taken under heavy ice conditions because the seawater flow was not secure. At other times we sampled every $2 \mathrm{~h}$, and in some areas (e.g. Mackenzie shelf, Bering Strait) every hour, measuring total alkalinity $\left(A_{T}\right)$ and $\mathrm{pH}$ from the seawater intake. We obtained a total of 242 discrete surface sampling locations where the flow of the surface water was adequate to provide reliable seawater samples that were free from air bubbles as the result of ice clogging in the seawater intake. In the Bering Strait, water column samples were collected from a 12-bottle rosette attached to a Conductivity-TemperatureDepth (CTD)-sensor. Table 1 shows the date and location of the stations in the Bering Strait. Sea surface salinity and temperature were continuously measured using a thermosalinograph SBE-21 (Seabird Electronics Inc.). A temperature sensor was also located at the sea water intake for temperature measurements of the incoming water (SST).

$\mathrm{A}_{\mathrm{T}}$ was determined by potentiometric titration in an open cell with $0.05 \mathrm{M} \mathrm{HCl}$, according to Haraldsson et al. (1997). The precision was computed from three replicate analyses of one sample at least twice daily and was determined to $\pm 2 \mu \mathrm{mol} \mathrm{kg}{ }^{-1}(\sim 0.1 \%)$. The accuracy was controlled against a certified reference material (CRM) supplied by Andrew Dickson (Scripps Institution of Oceanography, San Diego, USA) at the beginning and at the end of 20 samples.
The correction factor was approximately 1.002, corresponding to the difference of about $5 \mu \mathrm{mol} \mathrm{kg}^{-1}$. The variation in the CRM measurements was $\pm 8 \mu \mathrm{mol} \mathrm{kg}^{-1}$ for the whole cruise. $\mathrm{pH}$ was determined spectrophotometrically using the sulphonephtalein dye, $m$-cresol purple, as indicator (Clayton and Byrne, 1993; Lee and Millero, 1995). Prior to analysis the samples were thermostated to the temperature of $15^{\circ} \mathrm{C}$. Samples were measured in a 1-cm flow cell. The temperature was measured in the sample upstream of the flow cell. The analytical precision was estimated to $\pm 0.001 \mathrm{pH}$ units, which was determined by triplicate analysis of one sample every day. The magnitude of the perturbation of seawater $\mathrm{pH}$ caused by the addition of the indicator solution was calculated and corrected for using the method described in Chierici et al. (1999). The accuracy of spectrophotometric $\mathrm{pH}$ values is difficult to assess, since it relies ultimately on the physicochemical characteristics of the indicator solution. Commonly, the overall accuracy is determined by the accuracy of the temperature measurements and the accuracy in the determination of the equilibrium constants of the dye, which has been reported to be approximately $\pm 0.002 \mathrm{pH}$ units (Dickson, 1993). Here the quality of the $\mathrm{pH}$ measurements are checked by an independent assessment by comparing calculated values of fugacity of $\mathrm{CO}_{2}\left(f \mathrm{CO}_{2}\right)$ from $\mathrm{A}_{\mathrm{T}}$ and $\mathrm{pH}$ with measured $f \mathrm{CO}_{2}$ values from the same cruise.

\subsection{Calculations and internal consistency check}

We used $\mathrm{A}_{\mathrm{T}}, \mathrm{pH}$ at $15^{\circ} \mathrm{C}$, salinity and SST for each sample and the $\mathrm{CO}_{2}$ calculation program CO2SYS (Lewis and Wallace, 1998) to calculate, total dissolved inorganic carbon $\left(\mathrm{C}_{\mathrm{T}}\right)$, in situ $\mathrm{pH}$, the carbonate ion concentration $\left[\mathrm{CO}_{3}^{2-}\right]$, and the saturation state of aragonite ( $\Omega$ Ar) and calcite $(\Omega \mathrm{Ca})$. The calculations were performed at the total hydrogen ion scale $\left(\mathrm{pH}_{T}\right)$. For $\mathrm{KSO}_{4}$ we used the constant determined by Dickson (1990). $\quad \mathrm{C}_{\mathrm{T}}$ is defined as the sum of $\left[\mathrm{CO}_{2}^{*}\right]+\left[\mathrm{HCO}_{3}^{-}\right]+\left[\mathrm{CO}_{3}^{2-}\right]$ and $\mathrm{A}_{\mathrm{T}}$ is defined as $\left[\mathrm{HCO}_{3}\right]+2\left[\mathrm{CO}_{3}^{2-}\right]+\left[\mathrm{B}(\mathrm{OH})_{4}^{-}\right]+\left[\mathrm{OH}^{-}\right]-\left[\mathrm{H}^{+}\right]$, where $\left[\mathrm{CO}_{2}^{*}\right]$ is the sum of carbonic acid $\left[\mathrm{H}_{2} \mathrm{CO}_{3}\right]$ and $\left[\mathrm{CO}_{2}(\mathrm{aq})\right]$, $\left[\mathrm{HCO}_{3}^{-}\right]$ is bicarbonate, $\left[\mathrm{B}(\mathrm{OH})_{4}^{-}\right]$is borate, $\left[\mathrm{OH}^{-}\right]$is hydroxyl ion, and $\left[\mathrm{H}^{+}\right]$is the hydrogen ion. Because $\mathrm{CO}_{3}^{2-}$ can accept 2 protons, a given unit change results in a 2 -unit change in $\mathrm{A}_{\mathrm{T}}$, but only a 1 -unit change in $\mathrm{C}_{\mathrm{T}}$. Thus $\left[\mathrm{CO}_{3}^{2-}\right]$ is often approximated as the $\mathrm{A}_{\mathrm{T}}-\mathrm{C}_{\mathrm{T}}$, difference. Hence the relative abundance of these two conservative properties, e.g., the $A_{T}: C_{T}$ ratio, is useful to characterize ocean samples and the processes that affect Omega.

The appropriate equilibrium constants for different measurement parameter combinations when calculating $f \mathrm{CO}_{2}$ have been discussed for many years. Most of the studies investigating consistency and error in the calculated $\mathrm{CO}_{2}$ system parameters are based on calculations of $\mathrm{pH}$ and fugacity of $\mathrm{CO}_{2}\left(f \mathrm{CO}_{2}\right)$ from the combination of $\mathrm{A}_{\mathrm{T}}$ and $\mathrm{C}_{\mathrm{T}}$ (e.g. Wanninkhof et al., 1999; Johnson et al., 1999; Nondal 
Table 1. Location of water sampling stations in the eastern (E) and western (W) Bering Strait.

\begin{tabular}{|c|c|c|c|}
\hline Station\# & Sampling Date & Sampling sites & $\begin{array}{l}\text { Position } \\
\text { (Latitude, Longitude) }\end{array}$ \\
\hline 6 & 2005-08-01 & $\begin{array}{l}\text { E. Bering Strait } \\
\text { Vicinity of the Diomede Islands }\end{array}$ & $\begin{array}{l}65^{\circ} 45.3^{\prime} \mathrm{N} \\
168^{\circ} 41.6^{\prime} \mathrm{W}\end{array}$ \\
\hline 7 & 2005-08-01 & E. Bering Strait & $\begin{array}{l}65^{\circ} 45.4^{\prime} \mathrm{N} \\
168^{\circ} 28.6^{\prime} \mathrm{W}\end{array}$ \\
\hline 8 & 2005-08-01 & E. Bering Strait, Alaska channel & $\begin{array}{l}65^{\circ} 42^{\prime} \mathrm{N} \\
168^{\circ} 16^{\prime} \mathrm{W}\end{array}$ \\
\hline 9 & 2005-08-02 & South of E. Bering Strait & $\begin{array}{l}65^{\circ} 33.3^{\circ} \mathrm{N} \\
168^{\circ} 36^{\prime} \mathrm{W}\end{array}$ \\
\hline 10 & 2005-08-05 & W. Bering Strait, Russia & $\begin{array}{l}65^{\circ} 57^{\prime} \mathrm{N} \\
169^{\circ} 36^{\prime} \mathrm{W}\end{array}$ \\
\hline 11 & 2005-08-05 & W. Bering Strait, Russia & $\begin{array}{l}65^{\circ} 57^{\prime} \mathrm{N} \\
169^{\circ} 26^{\prime} \mathrm{W}\end{array}$ \\
\hline 12 & $2005-08-05$ & $\begin{array}{l}\text { W. Bering Strait } \\
\text { Vicinity of the Diomede Islands }\end{array}$ & $\begin{array}{l}65^{\circ} 51^{\prime} \mathrm{N} \\
169^{\circ} 24^{\prime} \mathrm{W}\end{array}$ \\
\hline
\end{tabular}

et al., 2009). Most studies have shown that the dissociation constants for carbonic acid $\left(K_{1}\right.$ and $\left.K_{2}\right)$ of Mehrbach et al. (1973, refit by Dickson and Millero, 1987) gave the best agreement with measured $f \mathrm{CO}_{2}$. However, this bias is temperature dependent and Wanninkhof et al. (1999) and Bates (2006) found only a small difference $(<5 \mu \mathrm{atm})$ at low temperatures $\left(<5^{\circ} \mathrm{C}\right)$ between different determinations of $K_{1}$ and $K_{2}$. The study by Clayton et al. (1995) and Chierici et al. (2004) used three measured parameters $\left(\mathrm{A}_{\mathrm{T}}, \mathrm{C}_{\mathrm{T}}, \mathrm{pH}\right)$ to investigate $\mathrm{CO}_{2}$ system consistency. Both studies found that the combination of $\mathrm{pH}$ with either $\mathrm{A}_{\mathrm{T}}$ or $\mathrm{C}_{\mathrm{T}}$ gave the smallest error in calculated $f \mathrm{CO}_{2}$. In this study, the choice of constants were based on the results from an internal consistency exercise using a comparison between the calculated surface water fugacity of carbon dioxide $\left(f \mathrm{CO}_{2}\right.$ calc) from measured $\mathrm{A}_{\mathrm{T}}$ and $\mathrm{pH}^{15}$ with measured $f \mathrm{CO}_{2} \mathrm{sw}$ performed at the same expedition. For details on the $f \mathrm{CO}_{2} \mathrm{sw}$ data along the cruise track, see Fransson et al. (2009). The $\mathrm{CO}_{2}$ system consistency check was performed using five different sets of $K_{1}$ and $K_{2}$; two of the sets that were refit by Dickson and Millero (1987), ie., Mehrbach et al. (1973, M), and Hansson (1973, H); Roy et al. (1993, 1994, Roy); Mojica-Prieto and Millero (2002, MM), which were corrected for $f \mathrm{CO}_{2}$, and the constants by Goyet and Poisson (1989, GP).

M, Roy and GP are chosen since their determination of dissociation constants are performed at lower temperatures $\left(-1^{\circ} \mathrm{C}\right.$ or $\left.0^{\circ} \mathrm{C}\right)$ and may be particularly suitable for $\mathrm{CO}_{2}$ system studies in polar water. Figure 4 shows a box-andwhisker plot with the resulting difference between $f \mathrm{CO}_{2} \mathrm{sw}$ and the calculated $f \mathrm{CO}_{2}$ based on the five sets of constants $\left(f \mathrm{CO}_{2} \mathrm{sw}-f \mathrm{CO}_{2}\right.$ calc). Table 2 gives the summary of the mean difference and standard deviation for all set of constants. From this we found that the $f \mathrm{CO}_{2}$ calculated from the Roy constants $\left(f \mathrm{CO}_{2}^{\text {Roy }}\right)$ had the best agree-

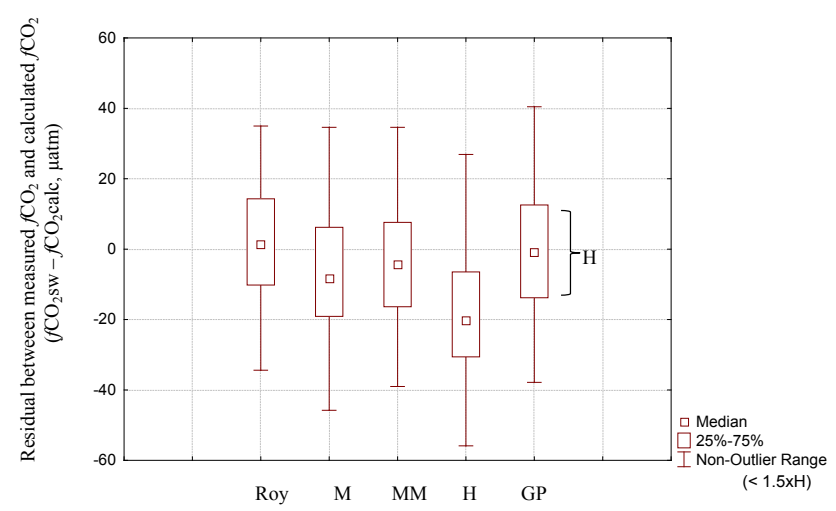

Fig. 4. The residual ( $\mu \mathrm{atm}$ ) between measured $f \mathrm{CO}_{2}$ in the surface water $\left(f \mathrm{CO}_{2} \mathrm{sw}\right)$ and the calculated $f \mathrm{CO}_{2}\left(f \mathrm{CO}_{2}\right.$ calc $)$ from the five sets of constants that were used in the study. Roy denotes the constants by Roy et al., 1993; M=Mehrbach et al., 1973; MM=Mojica-Prieto and Millero, 2002; H=Hansson, 1973, and $\mathrm{GP}=$ Goyet and Poisson, 1989. The 25th and 75th percentiles show the limits where $25 \%$ and $75 \%$ of the residuals falls below. The nonoutlier range is the range of values that fall below the upper outer limit of $\pm 1.5 \times$ the height of the box $(\mathrm{H})$. See Table 2 resulting mean and standard deviation values.

ment with $f \mathrm{CO}_{2} \mathrm{sw}$ (Fig. 4). The mean difference between the $f \mathrm{CO}_{2}^{\text {Roy }}$ and $f \mathrm{CO}_{2} \mathrm{sw}$ was $+0.7 \mu$ atm. The other set of constants resulted in $f \mathrm{CO}_{2}$ values that were high relative to the $f \mathrm{CO}_{2} \mathrm{sw}$ (Fig. 4). Based on this result we used the $K_{1}$ and $K_{2}$ dissociation constants estimated by Roy for our continued $\mathrm{CO}_{2}$ system calculations. Due to the few data points of measured nutrient data we neither used phosphate $\left(\mathrm{PO}_{4}\right)$ nor silicic acid $\left(\mathrm{SiOH}_{4}\right)$ in our calculations. This introduced the error of $0.04 \%$ in our estimates of $\left[\mathrm{CO}_{3}^{2-}\right]$, $(\Omega \mathrm{Ar})$ and $(\Omega \mathrm{Ca})$, based on the mean $\mathrm{PO}_{4}$ and $\mathrm{SiOH}_{4}$ con- 


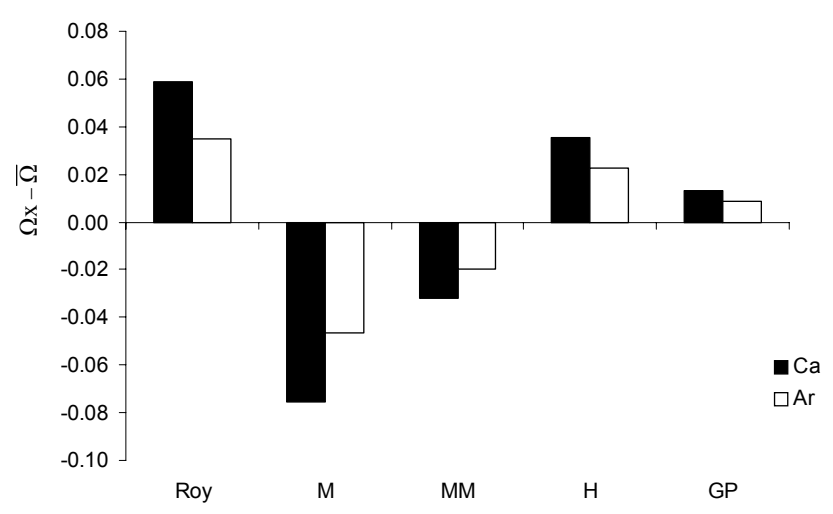

Fig. 5. The difference in $\Omega \mathrm{Ca}$ (black) and $\Omega \mathrm{Ar}$ (white) between the estimate of $\Omega$ from each of the five sets of constants $(\Omega \mathrm{X})$ minus the average of all five sets of constants $(\bar{\Omega})$. See Fig. 4 for denotation of five set of constants.

Table 2. The mean difference and standard deviation of the measured $f \mathrm{CO}_{2}\left(f \mathrm{CO}_{2} \mathrm{sw}\right)$ minus calculated $f \mathrm{CO}_{2}$ from each of the five sets of constants calculated $f \mathrm{CO}_{2}$ from $\mathrm{A}_{\mathrm{T}}$ and $\mathrm{pH}$.

\begin{tabular}{lll}
\hline$f \mathrm{CO}_{2} \mathrm{sw}-f \mathrm{CO}_{2}$ calc & $\begin{array}{l}\text { Mean } \\
(\mu \mathrm{atm})\end{array}$ & $\begin{array}{l}\text { Standard } \\
\text { deviation } \\
(\mu \text { atm })\end{array}$ \\
\hline Roy & +0.7 & \pm 16.3 \\
M & -7.1 & \pm 16.7 \\
MP & -4.3 & \pm 16.7 \\
H & -18.9 & \pm 17.6 \\
GP & -1.5 & \pm 18.2 \\
\hline
\end{tabular}

centrations of $1 \mu \mathrm{M}$ and $7 \mu \mathrm{M}$, respectively (unpublished data from Beringia, 2005). The concentration of calcium, $\left[\mathrm{Ca}^{2+}\right]$, is assumed to be proportional to the salinity according to $(10.28 \times \mathrm{S} / 35 \mu \mathrm{mol} \mathrm{kg}-1)$. The thermodynamic solubility products for aragonite and calcite (Ksp) are from Mucci (1983). The CO2SYS program uses the pressure correction of Ksp by Ingle (1975). Ksp was calculated for both calcite and aragonite and the saturations states were given in terms $\Omega=\left[\mathrm{CO}_{3}^{2-}\right] \times\left[\mathrm{Ca}^{2+}\right] / \mathrm{Ksp}$. The values of $\Omega<1$ represent undersaturated conditions, whereas the values of $\Omega>1$ represent conditions of supersaturation. We evaluated the difference in the calculated $\Omega$ resulting from the five set of constants presented in the previous section based on the difference between the average for all $\Omega$ values $(\bar{\Omega})$ and the average value from the individual estimate $\left(\Omega_{X}\right)$ from the five set of constants. The $x$ indicates the set of constants used, e.g. $\Omega_{\text {Roy }}$ is the mean value of $\Omega$ based on estimate using Roy $K_{1}$ and $K_{2}$. From Fig. 5 we found that the $\Omega$ calculated from Roy, H, and GP constants were higher than the average for all values and the values based on $\mathrm{M}$ and $\mathrm{MM}$ were lower than the mean for all $\Omega$. The GP and MM constants

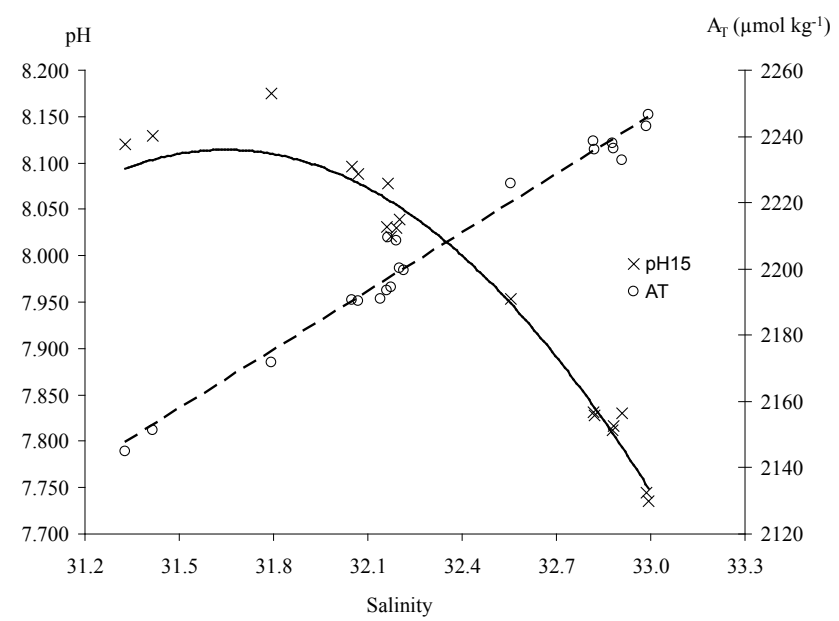

Fig. 6. Relationship of measured $\mathrm{A}_{\mathrm{T}}$ (crosses) and $\mathrm{pH}^{15}$ (open circles) to salinity, including the derived regressions described in the text (solid lines).

gave the smallest bias relative to the mean for all $\Omega$ of 0.01 and -0.02 , respectively. This showed that by using the Roy constants we obtained $\Omega$ values that resulted in a higher saturation state, thus the marine environment may be closer to the threshold of $\mathrm{CaCO}_{3}$ dissolution than what this study showed.

In the Bering Strait, we used the high resolution salinity (S) data along with lower resolution data on $\mathrm{A}_{\mathrm{T}}$ and $\mathrm{pH}^{15}$ to construct relationships between salinity and $\mathrm{A}_{\mathrm{T}}$ and $\mathrm{pH}^{15} . \quad \mathrm{A}_{\mathrm{T}}$ in the Bering Strait $\left(A_{\mathrm{TbeS}}\right)$ was calculated using the equation $A_{\text {TbeStr }}=58.854 \times \mathrm{S}+303.99$ $\left(r^{2}=0.974\right.$, Standard error $\left.= \pm 5 \mu \mathrm{mol} \mathrm{kg}-1, N=21\right)$. Following correction of $\mathrm{pH}$ measurements to a standard temperature, the derived relationship with salinity is $\mathrm{pH}^{15 \mathrm{BeStr}}=-0.215 \times \mathrm{S}^{2}+13.622 \times \mathrm{S}-207.65\left(r^{2}=0.947\right.$, Standard error $= \pm 0.028, N=19$ ), obtained from the polynomial relationship with $\mathrm{S}$. The polynomial $\mathrm{pH}-\mathrm{S}$ dependency was likely due to the nonlinear $\mathrm{CO}_{2}$ dependency. Figure 6 shows the salinity relationship with $A_{\text {TbeStr }}$ and $\mathrm{pH}^{15 \mathrm{BeStr}}$. Based on the standard error in the salinity relationships for $\mathrm{A}_{\mathrm{T}}$ and $\mathrm{pH}^{15}$, the errors are $\pm 6 \mu \mathrm{mol} \mathrm{kg}^{-1}$ for $\mathrm{C}_{\mathrm{T}}, \pm 0.15$ for $\Omega \mathrm{Ca}$, and \pm 0.10 for $\Omega$ Ar.

\section{Results}

$\mathrm{A}_{\mathrm{T}}$ generally covaries with salinity. This was also observed in our study and the high $A_{T}$ of $>2200 \mu \mathrm{mol} \mathrm{kg}^{-1}$ in the Labrador Sea is the result of the influence of high salinity Atlantic water in the Labrador Sea. This water is diluted and $A_{T}$ and $C_{T}$ decreases as it enters the CAA when it meets low $A_{T}$ and $\mathrm{C}_{\mathrm{T}}$ sea-ice melt water (Fig. 7). This is also manifested by the generally low $\mathrm{A}_{\mathrm{T}}$ values in the CAA $\left(\sim 1800 \mu \mathrm{mol} \mathrm{kg}^{-1}\right)$, and in the southeastern Beaufort Sea, where there is strong influence of the Mackenzie River. Strong gradients in all study parameters were observed between the CAA and the 
(a)

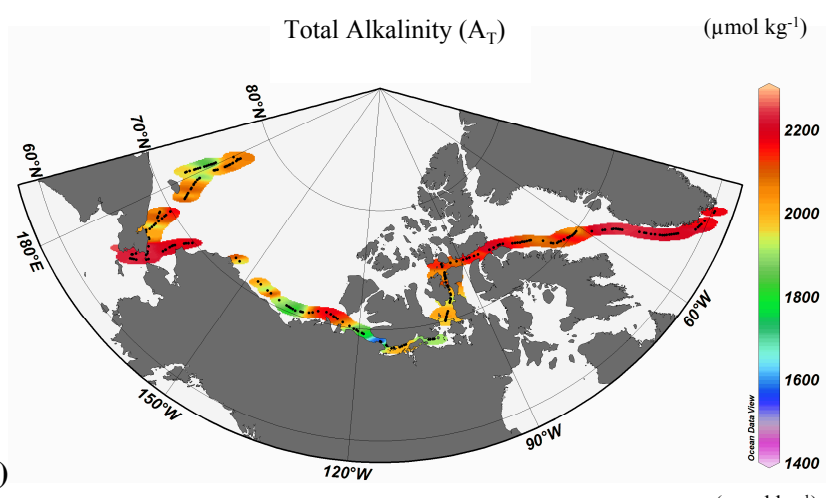

(b)

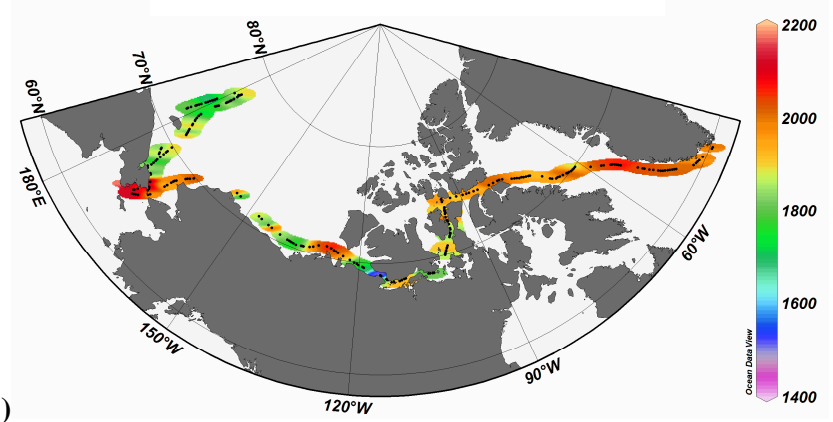

Fig. 7. Measured surface-water (a) total alkalinity $\left(\mathrm{A}_{\mathrm{T}}\right.$, $\mu \mathrm{mol} \mathrm{kg}-1)$ and (b) the computed total dissolved inorganic carbon $\left(\mathrm{C}_{\mathrm{T}}, \mu \mathrm{mol} \mathrm{kg}{ }^{-1}\right)$ as calculated from $\mathrm{A}_{\mathrm{T}}$ and $\mathrm{pH}$ at $15^{\circ} \mathrm{C}$.

area south of the Banks Island. In this relatively short distance, $\mathrm{A}_{\mathrm{T}}$ increased by more than $300 \mu \mathrm{mol} \mathrm{kg}{ }^{-1}$, salinity from 27 to 32, and temperature rose from 0 to $6^{\circ} \mathrm{C}$. Other areas with high $\mathrm{A}_{\mathrm{T}}$ and low $\mathrm{pH}$ were observed around the Chukchi Peninsula and the Chukchi Plateau, probably due to the effect of upwelling, as suggested by the elevated salinity at these locations (Fig. 2). Large $\mathrm{A}_{\mathrm{T}}$ variability was observed in the Chukchi Sea and in the area surrounding Wrangel Island, where $\mathrm{A}_{\mathrm{T}}$ ranged from $2200 \mu \mathrm{mol} \mathrm{kg}^{-1}$ to $1800 \mu \mathrm{mol} \mathrm{kg}^{-1}$.

The in situ pH (Fig. 8a) varied between 7.933 and 8.515. Low $\mathrm{pH}$ was observed in the freshwater-rich regions (CAA and the Mackenzie shelf area). The lowest in situ $\mathrm{pH}$ value of 7.933 was observed at the upwelling sites around Cape Bathurst (CB, Fig. 1) and south of the Chukchi Peninsula (ChP, Fig. 1). Relative to other areas, in situ $\mathrm{pH}$ was reduced by $0.2 \mathrm{pH}$ units or more particularly around the Chukchi Peninsula. The driver of these low $\mathrm{pH}$ waters was probably upwelling of saline subsurface waters that are highly enriched in $\mathrm{CO}_{2}$ from the remineralization of organic matter. The area of highest $\mathrm{pH}(>8.35$ in in situ $\mathrm{pH})$ was observed north of the Wrangel Island. Here we also found low $\mathrm{C}_{\mathrm{T}}$ (Fig. 7b), probably owing to the combination of sea-ice melt water and intense $\mathrm{CO}_{2}$ drawdown by primary production. The calculated $\left[\mathrm{CO}_{3}^{2-}\right]$ concentrations varied from 50 to

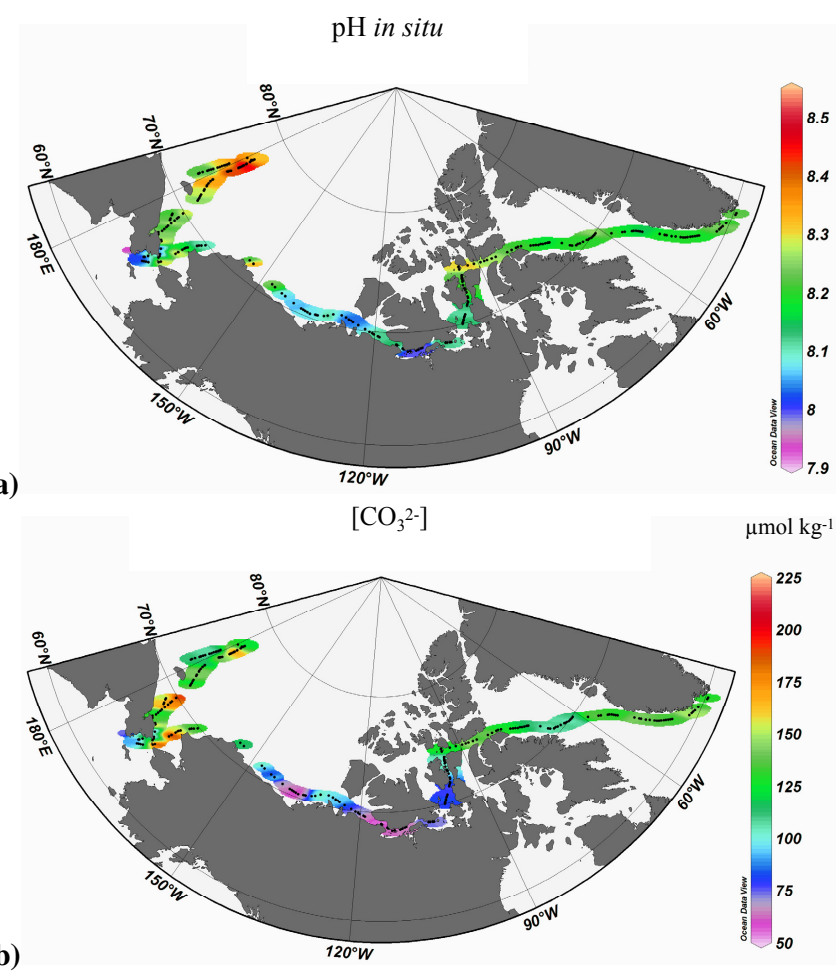

Fig. 8. Surface-water (a) in situ $\mathrm{pH}$, and (b) the carbonate concentration $\left(\mathrm{CO}_{3}^{2-}, \mu \mathrm{mol} \mathrm{kg}{ }^{-1}\right)$, as calculated from $\mathrm{A}_{\mathrm{T}}$ and $\mathrm{pH}$ at $15^{\circ} \mathrm{C}$.

$220 \mu \mathrm{mol} \mathrm{kg}^{-1}$, with the lowest values in the CAA, Mackenzie area, and southern ChP (Fig. 8b). For all parameters, the Chukchi Sea had the largest regional variability of $\left[\mathrm{CO}_{3}^{2-}\right]$, exhibiting both the lowest and the highest $\left[\mathrm{CO}_{3}^{2-}\right]$. The influence of the Atlantic water explained the high $\left[\mathrm{CO}_{3}^{2-}\right]$ in the Labrador Sea.

The saturation values of $\Omega \mathrm{Ca}$ varied between 1.3 and 4.9, and for $\Omega$ Ar between 0.8 and 3.1 (Fig. 9). The lowest saturation in the CAA and on the Mackenzie shelf as well as the lowest $\left[\mathrm{CO}_{3}^{2-}\right]$ were associated with the relatively high concentrations of cold and fresh water. We observed surface undersaturation $(\Omega \mathrm{Ar}<1)$ at 11 sites, sampled in the CAA and on the MS.

In the Bering Strait $(\mathrm{BeS})$, there were clear $\mathrm{A}_{\mathrm{T}}, \mathrm{pH}$, and $\mathrm{C}_{\mathrm{T}}$ gradients, both vertically and horizontally (Fig. 10). Highest $A_{T}$ and $C_{T}$ values were observed in the west and lowest $A_{T}$ and $\mathrm{C}_{\mathrm{T}}$ values in the east. Highest $\mathrm{C}_{\mathrm{T}}$ and $\mathrm{A}_{\mathrm{T}}$ and lowest $\mathrm{pH}$ (in situ $\mathrm{pH} \sim 7.97$ ) were observed in the western channel below $10 \mathrm{~m}$, and lowest $\mathrm{C}_{\mathrm{T}}$ and highest $\mathrm{pH}$ were found below 10 meter in the eastern channel. In the west, the high $\mathrm{A}_{\mathrm{T}}$ and high $\mathrm{C}_{\mathrm{T}}\left(2150 \mu \mathrm{mol} \mathrm{kg}^{-1}\right)$ and low $\mathrm{pH}$ suggest that $\mathrm{CO}_{2}$ rich subsurface water explains the low $\left[\mathrm{CO}_{3}^{2-}\right]$, low $\Omega \mathrm{Ca}$ and $\Omega \operatorname{Ar}(1.4$ and 1.2, respectively; Fig. 11). However, no undersaturation $(\Omega<1)$ was observed in the water column of the Bering Strait. 
(a)

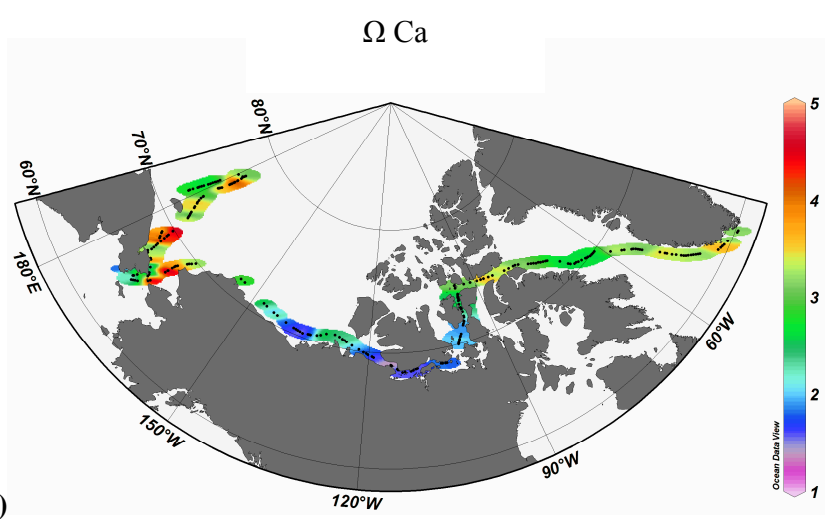

$\Omega \mathrm{Ar}$

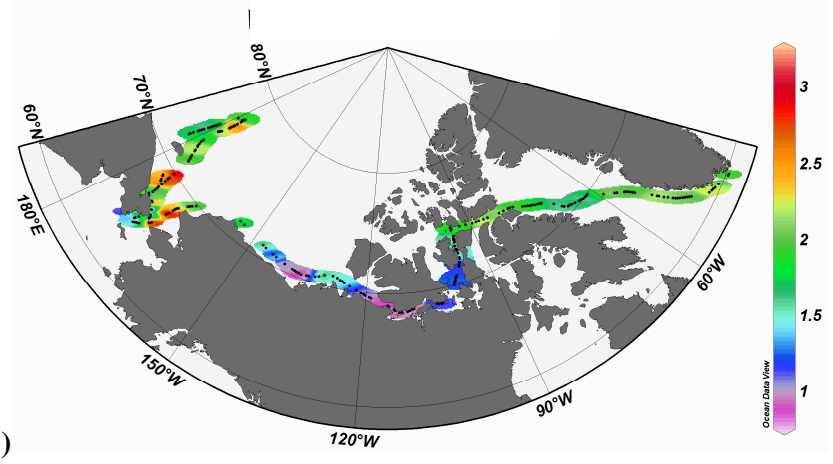

(b)

Fig. 9. Saturation state for (a) calcite $(\Omega \mathrm{Ca})$ and (b) aragonite ( $\Omega$ Ar).

\section{Discussion}

In the upper ocean, the $\Omega \mathrm{Ca}$ and the $\Omega \mathrm{Ar}$ are affected by processes such as air-sea $\mathrm{CO}_{2}$ exchange, biological production and respiration, physical mixing, freshwater input, and changes in temperature. In this section we discuss the variability in $\Omega \mathrm{Ca}$ and $\Omega \mathrm{Ar}$ values due to these processes using $\mathrm{A}_{\mathrm{T}}: \mathrm{C}_{\mathrm{T}}$ ratio (Fig. 12). The $\mathrm{A}_{\mathrm{T}}: \mathrm{C}_{\mathrm{T}}$ ratio varied in the study area due to the different factors such as freshwater, biological primary production and physical upwelling. High $\mathrm{A}_{\mathrm{T}}: \mathrm{C}_{\mathrm{T}}$ ratios were found in the Labrador Sea (LaS), indicating the influence of Atlantic water inflow which carries relatively high levels of $\left[\mathrm{CO}_{3}^{2-}\right]$. The aragonite undersaturation $(\Omega \mathrm{Ar} \sim 0.9)$ that we found in the ice covered CAA was likely the result of the gradual dilution of the $\left[\mathrm{CO}_{3}^{2-}\right]$ due to the addition of sea-ice meltwater, which has low $\mathrm{A}_{\mathrm{T}}$ and $C_{T}$. The $A_{T}: C_{T}$ ratio was close to 1.0 in the river influenced Mackenzie shelf, which means that $A_{T}$ and $C_{T}$ have similar concentrations, meaning that $\left[\mathrm{CO}_{3}^{2-}\right]$ is low. These undersaturated waters may impose severe constraints to organisms that secrete aragonite to build their skeletal material.

The highest $\mathrm{pH}$ values were observed north of the Wrangel Island (WI), which coincided with low $\mathrm{C}_{\mathrm{T}}$ values and relatively high $\mathrm{A}_{T}: \mathrm{C}_{\mathrm{T}}$ ratio (Fig. 12). During biological production $\mathrm{C}_{\mathrm{T}}$ is consumed (increase in $\mathrm{pH}$ ) which increases $\left[\mathrm{CO}_{3}^{2-}\right]$ and the saturation state for aragonite and calcite.

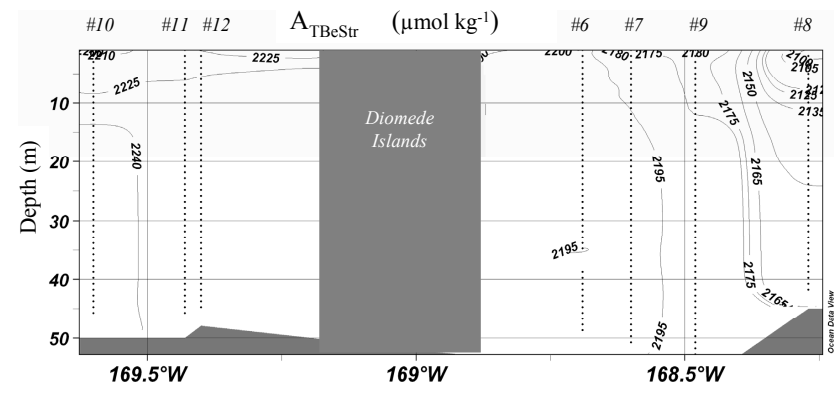

(a)

$$
\text { W. Bering Strait }
$$

$\mathrm{pH}$ in situ (pHisBeStr)

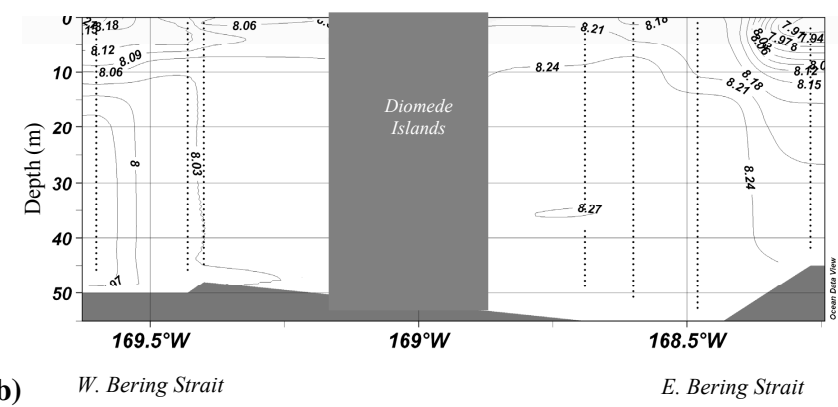

Fig. 10. Cross section of (a) $A_{\text {TbeStr }}\left(\mu \mathrm{mol} \mathrm{kg}^{-1}\right)$, (b) $\mathrm{pH}^{\text {isBeStr }}$, and (c) $\mathrm{C}_{\mathrm{T}}\left(\mu \mathrm{mol} \mathrm{kg}^{-1}\right)$ in the Bering Strait. The values were calculated based on the salinity relationships with measured $\mathrm{A}_{\mathrm{T}}$ and $\mathrm{pH}^{15}$ (see Fig. 6). $\mathrm{C}_{\mathrm{T}}$ is calculated from $A_{\text {TbeStr }}$ and $\mathrm{pH}^{(15) \mathrm{BeStr}}$. The sampling stations are indicated by station numbers \#6 to \#12, positions are given in Table 1.

Substantial primary production was indicated by enhanced chlorophyll- $a$ (Fransson et al., 2009) suggesting that associated biological $\mathrm{CO}_{2}$ drawdown in this region was responsible for the high $\left[\mathrm{CO}_{3}^{2-}\right]$ (Fig. 8), and the high $\Omega \mathrm{Ca}$ and $\Omega \mathrm{Ar}$ (Fig. 9) during August 2005. The large variability of the carbonate system parameters in the Chukchi Sea appears to result from the combination of varying sea ice cover, physical mixing, and inflow of Pacific water through the Bering Strait. The Pacific water supplies inorganic nutrients and supports one of the highest rates of biological production in the world ocean (Walsh et al., 1989). In the western Bering Strait, the cold and saline Anadyr Current (AC) brings in water with high $\mathrm{A}_{\mathrm{T}}\left(2240 \mu \mathrm{mol} \mathrm{kg}^{-1}\right)$, and high $\mathrm{C}_{\mathrm{T}}\left(2150 \mu \mathrm{mol} \mathrm{kg}^{-1}\right)$, low $\mathrm{A}_{\mathrm{T}}: \mathrm{C}_{\mathrm{T}}$ ratio (1.04) and low $\mathrm{pH}(\mathrm{pH}<8)$, probably derived largely from intense remineralization of organic matter. As a result, this water has the lowest $\Omega A r(\sim 1.25)$ found in the Bering Strait.

At several locations we found the signature of the upwelling of subsurface waters to the surface, such as the area close to the Cape Bathurst (Barber and Hanesiak, 2004) and the southern Chukchi Peninsula. In this area salinity, $A_{T}$ and $\mathrm{C}_{\mathrm{T}}$ were relatively high and $\mathrm{pH}$ was low, implying upwelling of $\mathrm{CO}_{2}$-rich subsurface water containing high $\mathrm{C}_{\mathrm{T}}$ due to the extensive remineralization of organic matter deeper in 


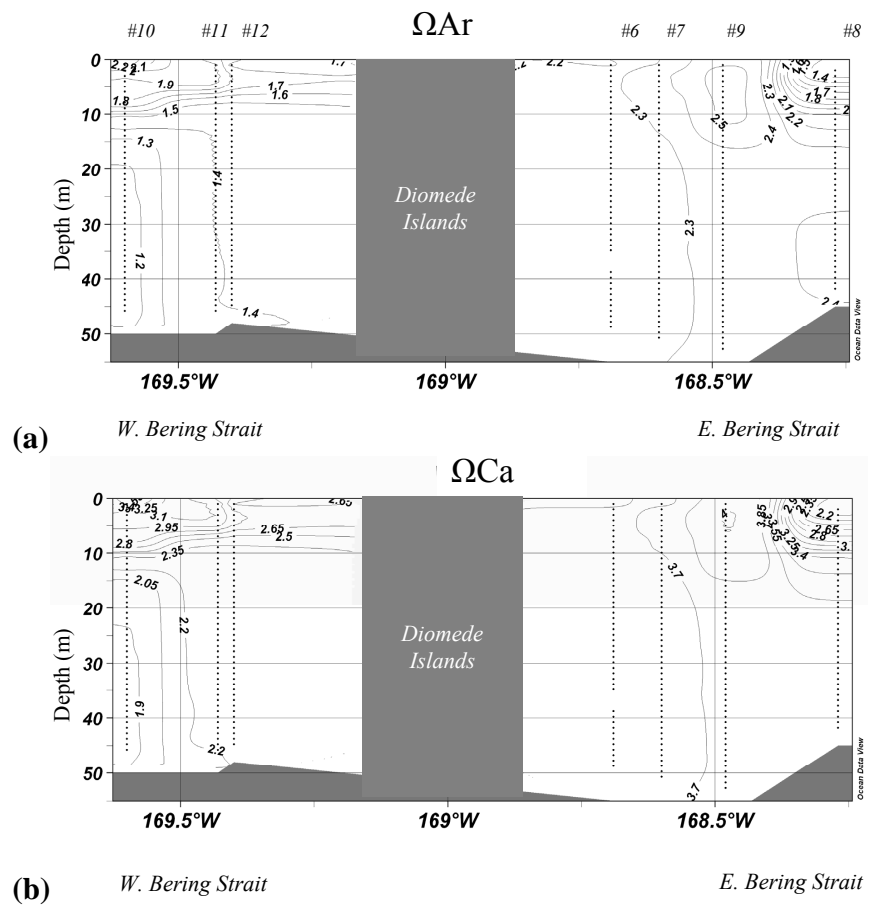

Fig. 11. The saturation state of (a) aragonite ( $\Omega$ Ar) and (b) calcite $(\Omega \mathrm{Ca}$ ) in the Bering Strait. Values of $\Omega<1$ represent undersaturated conditions, and values of $\Omega>1$ represent conditions of oversaturation. The sampling stations are indicated by station numbers \#6 to $\# 12$, positions are given in Table 1 .

subsurface waters. This was indicated by the high $f \mathrm{CO}_{2}$ values measured in this area by Fransson et al. (2009). The $\mathrm{A}_{\mathrm{T}}: \mathrm{C}_{\mathrm{T}}$ ratio was low in both upwelling areas, especially in the Chukchi Peninsula where the lowest $\mathrm{pH}$ and highest $\mathrm{C}_{\mathrm{T}}$ were measured, consistent with low $\left[\mathrm{CO}_{3}^{2-}\right], \Omega \mathrm{Ar}(1$ to 1.5$)$, and $\Omega \mathrm{Ca}$ (1.5 to 2.2 ).

Macdonald et al. (2002) found that the eastward diversion of Eurasian river runoff to the western Arctic Ocean was linked to high North Atlantic Oscillation (NAO), which explained most of the recent freshening of the CAA. A fresher Arctic Ocean would affect the marine $\mathrm{CO}_{2}$ system's saturation states, which could diminish calcification by marine calcifiers, especially those that secrete less stable forms (aragonite and High-Mg calcite).

The Arctic Ocean and its marginal seas are warming faster than other areas (Comiso, 2003; IPCC, 2007). Ice coverage in summer 2007 reached a record minimum, with ice extent declining by $42 \%$ compared to conditions in the 1980 s (Maslanik et al., 2007). More sea-ice melt during summer will lead to more stratification of the surface. Although the light penetration of the water column will increase as well as the growing season, favourable for phytoplankton growth, the freshening of the surface water would lead to less $\left[\mathrm{CO}_{3}^{2-}\right]$ due to dilution, hampering $\mathrm{CaCO}_{3}$ formation. Increased seaice melt could also have implications for the benthic organ-

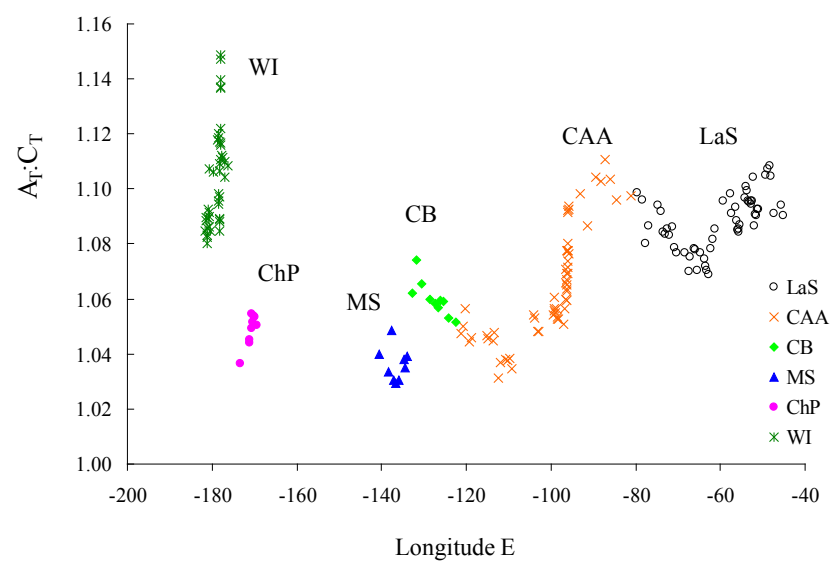

Fig. 12. The $A_{T}: C_{T}$ ratio versus longitude in Labrador Sea (LaS; black open circle), Canadian Arctic Archipelago (CAA; orange cross), Cape Bathurst (CB; green closed diamond), Mackenzie shelf (MS; blue filled triangle), South Chukchi Peninsula (ChP; purple closed circle), and Wrangel Island (WI; dark green cross).

isms living in the sediments of the shallow shelf seas in the Arctic Ocean, such as echinoderms and molluscs (Shirayama and Thornton, 2005). In our study we observed the lowest $\left[\mathrm{CO}_{3}^{2-}\right]$ in areas with large sea-ice melt water fractions, computed by Fransson et al. (2009). A future increase in the sea-ice melt water fraction would decrease $\left[\mathrm{CO}_{3}^{2-}\right]$, thereby reducing $\mathrm{CaCO}_{3}$ saturation.

We found lowest $\Omega$ values in areas with freshwater contribution from either river runoff or sea ice melt water, consistent with the idea that increased freshwater input results in decreased saturation state. This is also consistent with the finding that most of the Arctic river end-member have $\Omega$ values that are close to zero (Salisbury et al., 2008) and that rivers are net heterotrophic with high $f \mathrm{CO}_{2}$ content (Chen and Borges, 2009). Changes in the input of $A_{T}$ by river runoff will also likely affect Arctic Ocean $\left[\mathrm{CO}_{3}^{2}\right]$. The $\mathrm{A}_{\mathrm{T}}$ and $\mathrm{C}_{\mathrm{T}}$ values in the Arctic rivers are typically above $1000 \mu \mathrm{mol} \mathrm{kg}^{-1}$ (Olsson and Anderson, 1997), owing to the combination of decaying organic matter (mainly carbohydrates) and dissolution of metal (mainly calcium) carbonates in the drainage basin (Eq. 3),

$\mathrm{CaCO}_{3}(\mathrm{~s})+\mathrm{CH}_{2} \mathrm{O}($ org $)+\mathrm{O}_{2} \rightarrow \mathrm{Ca}^{2+}+2 \mathrm{HCO}_{3}^{-}$

The rivers draining the American continent are significantly higher in $\mathrm{A}_{\mathrm{T}}$ and $\mathrm{C}_{\mathrm{T}}$ relative to the Siberian rivers (Olsson and Anderson, 1997). This is the result of the different mineralogies of the drainage basins (Naidu, 1974). On the sandy, terraced banks of the Mackenzie and the Yukon Rivers there is enhanced erosion, whereas Siberian rivers pass through huge marsh lowlands, which favours deposition (Pocklington, 1987). The Mackenzie River has relatively high $\mathrm{A}_{\mathrm{T}}$ ( $\sim 1500 \mu \mathrm{mol} \mathrm{kg}{ }^{-1}$, Fransson et al., 2009) compared to other Arctic rivers, which are similar to the rivers draining into 
southern Baltic Sea (Hjalmarsson et al., 2008). A recent study investigating the trends of $\mathrm{A}_{\mathrm{T}}$ in the rivers entering the Baltic Sea, showed that during the last century, $A_{T}$ has increased in rivers flowing over drainage basins that contain metal carbonates, whereas $\mathrm{A}_{T}$ has decreased in rivers flowing over low carbonate environment, such as granite (Hjalmarsson et al., 2008). Increased freshwater addition to the Arctic Ocean in the future would likely decrease its surface $\left[\mathrm{CO}_{3}^{2-}\right]$ as well as its buffer capacity.

Acknowledgement. This is a contribution to The Swedish Science Council (VR project \#2004-4034) and to the Swedish Research Council for Environment, Agricultural Sciences and Spatial Planning (Formas project \#2004-797). We are grateful to Are Olsen and two anonymous reviewers for constructive comments that significantly improved the manuscript. We are grateful to the owners, captains, officers and the crew of the IB Oden, Sweden, for their support. We also thank the Swedish Polar Research Secretariat for the cruise planning and logistical support both before and during the cruise. Thanks also to the developers of the plotting software Ocean Data View (Schlitzer, 2002).

Edited by: J. Orr

\section{References}

Barber, D. G. and Hanesiak, J. M.: Meterological forcing of sea ice concentrations in the southern Beaufort Sea over the period 1979 to 2000, J. Geophys. Res., 109, C06014, doi:10.1029/2003JC002027, 2004.

Bates, N. R.: Air-sea $\mathrm{CO}_{2}$ fluxes and the continental shelf pump of carbon in the Chukchi Sea adjacent to the Arctic Ocean, J. Geophys. Res., 111, C10013, doi:10.129/2005JC003083, 2006.

Broecker, W. S. and Takahashi, T.: Neutralization of fossil fuel $\mathrm{CO}_{2}$ by marine calcium carbonate, in: The Fate of Fossil Fuel in the Oceans, edited by: Andersen, N. R. and Malahoff, A., 213-241, Plenum Press, New York, 1977.

Caldeira, K. and Wickett, M. E.: Anthropogenic carbon and oceanic ocean pH, Nature, 425, 365 pp., 2003.

Carmack, E., Barber, D., Christensen, J., Macdonald, R., Rudels, B., and Sakshaug, E.: Climate variability and physical forcing of the food webs and the carbon budget on panarctic shelves, Progr. Oceanogr., 71, 145-181, 2006.

Chen, C. T. A. and Borges, A. V.: Reconciling opposing views on carbon cycling in the coastal ocean: Continental shelves as sinks and the near-shore ecosystems as sources of atmospheric $\mathrm{CO}_{2}$, Deep-Sea Res. II, in press, 2009.

Chierici, M., Fransson, A., and Anderson, L. G.: Influence of mcresol purple indicator additions on the $\mathrm{pH}$ of seawater samples: correction factors evaluated from a chemical speciation model, Mar. Chem., 65, 281-290, 1999.

Chierici, M., Fransson, A., Turner, D. R., Pakhomov, E. A., and Froneman, P. W.: Variability in $\mathrm{pH}, f \mathrm{CO}_{2}$, oxygen and flux of $\mathrm{CO}_{2}$ in the surface water along a transect in the Atlantic sector of the Southern Ocean, Deep-Sea Res. II, 51, 2773-2787, 2004.

CISA report: Seasonal summary for Canadian Arctic waters - summer 2005, Canadian Ice Service, 2005.
Clayton, T. D. and Byrne, R. H.: Spectrophotometric seawater $\mathrm{pH}$ measurements: total hydrogen ion concentration scale calibration of m-cresol purple and at-sea results, Deep-Sea Res. I, 40(10), 2115-2129, 1993.

Comiso, J. C.: Warming Trends in the Arctic, J. Climate, 16(21), 3498-3510, 2003.

Dickson, A. G. and Millero, F. J.: A comparison of the equilibrium constants for the dissociation of carbonic acid in seawater media, Deep-Sea Res. I, 34, 1733-1743, 1987.

Dickson, A. G.: Standard potential of the reaction: $\mathrm{AgCl}(\mathrm{s})+\mathrm{O}$ $\mathrm{H}_{2}(\mathrm{~g})=\mathrm{Ag}(\mathrm{s})+\mathrm{HCl}(\mathrm{aq})$, and the standard acidity constant of the ion $\mathrm{HSO}_{4}$ in synthetic seawater from 273.15 to $318.15 \mathrm{~K}, \mathrm{~J}$. Chem. Thermodyn., 22, 113-127, 1990.

Dickson, A. G.: The measurement of sea water pH, Mar. Chem., 44, 131-142, 1993.

Feely, R. A., Sabine, C. L., Lee, K., Berelson, W., Kleypas, J., Fabry, V. J., and Millero, F. J.: Impact of anthropogenic $\mathrm{CO}_{2}$ on the $\mathrm{CaCO}_{3}$ system in the ocean, Science, 305, 362-366, 2004.

Feely, R. A., Sabine, C. L., Martin Hernandez-Ayon, J., Ianson, D., and Hales, B.: Evidence for Upwelling of Corrosive "Acidified" Water onto the Continental Shelf, Science 320, 5882, 14901492, doi:10.1126/science.1155676, 2008.

Fransson, A., Chierici, M., and Nojiri, Y.: New insights into the spatial variability of the surface water carbon dioxide in varying sea ice conditions in the Arctic Ocean, Continental Shelf Research, 29(10), 1317-1328, doi:10.1016/j.csr.2009.03.008, 2009.

Hansson, I.: A new set of dissociation constants for carbonic acid and boric acid in seawater, Deep-Sea Res., 20, 461-478, 1973.

Gattuso, J.-P., Frankignoulle, M., Bourge, I., Romaine, S., and Buddmeier, R. W.: Effect of calcium carbonate saturation of seawater on coral calcification, Global Planetary Change, 18, 37-46, 1998.

Goyet, C. and Poisson, A.: New determination of carbonic acid dissociation constants in seawater as a function of temperature and salinity, Deep-Sea Res., 36, 1635-1654, 1989.

Grebmaier, J. M., McRoy, C. P., and Feder, H. M.: Pelagic-benthic coupling on the shelf of the northern Bering and Chukchi Seas. I. Food supply source and benthic biomass, Mar. Ecol. Progr. Ser., 48, 57-67, 1988.

Hansson, I.: A new set of acidity constants for carbonic acid and boric acid in seawater, Deep-Sea Res., 20, 461-478, 1973.

Haraldsson, C., Anderson, L. G., Hassellöv, M., Hulth, S., and Olsson, K.: Rapid, high-precision potentiometric titration of alkalinity in the ocean and sediment pore waters, Deep-Sea Res. I, 44, 2031-2044, 1997.

Hjalmarsson, S., Wesslander, K., Anderson, L. G., Omstedt, A., Pertillä, M., and Mintrop, L.: Distribution, long-term development and mass balance calculation of total alkalinity in the Baltic Sea, Continental Shelf Res., 28, 593-601, 2008.

Ingle, S. E.: Solubility of calcite in the ocean, Marine Chem., 3, 301-319, 1975.

Johnson, K. M., Körtzinger, A., Mintrop, L., Duinker, J. C., Wallace, D. W. R.: Coulometric total carbon dioxide analysis for marine studies: measurements and internal consistency of underway TCO2 concentrations, Mar. Chem., 67, 123-144, 1999.

Jutterström, S. and Anderson, L. G.: The saturation of calcite and aragonite in the Arctic Ocean, Mar. Chem., 94, 101-110, 2005.

Lee, K. and Millero, F. J.: Thermodynamic studies of the carbonate system in seawater, Deep-Sea Res. I, 42, 2035-2061, 1995. 
Lewis, E. and Wallace, D. W. R.: Program Developed for $\mathrm{CO}_{2}$ Systems Calculations. ORNL/CDIAC-105, Carbon Dioxide Information Analysis Centre, Oak Ridge National Laboratory, US Department of Energy, Oak Ridge, Tennessee, 1998.

Macdonald, R. W., McLaughlin, F. A., and Carmack, E. C.: Fresh water and its sources during the SHEBA drift in the Canada Basin of the Arctic Ocean, Deep-Sea Res. I, 49, 1769-1785, 2002.

Maslanik, J. A., Fowler, C., Stroeve, J., Drobot, S., Zwally, J., Yi, D., and Emery, W.: A younger, thinner Arctic ice cover: Increased potential for rapid, extensive sea-ice loss, Geophys. Res. Lett., 34(24), L24501, doi:10.1029/2007GL032043, 2007.

Mehrbach, C., Culberson, C. H., Hawley, J. E., and Pytkowicz, R. M.: Measurement of the apparent dissociation constants of carbonic acid in seawater at atmospheric pressure, Limnol. Oceanogr., 18, 897-907, 1973.

Mojica-Prieto, F. J. and Millero, F. J.: The values of $\mathrm{pK} 1+\mathrm{pK} 2$ for the dissociation of carbonic acid in seawater, Geochim. Cosmochim. Acta, 66(14), 2529-2540, 2002.

Mucci, A.: The solubility of calcite and aragonite in seawater at various salinities, temperatures and at one atmosphere pressure, Am. J. Sci., 283, 781-799, 1983.

Naidu, A. S.: Sedimentation in the Beaufort Sea: a synthesis, in: Marine Geology and Oceanography of the Arctic Seas, edtied by: Rosenberg-Herman, Y., 173-190, Springer, Berlin, 1974.

Nondal, G., Bellerby, R. G. J., Olsen, A., Johannessen, T., and Olafsson, J.: Optimal evaluation of the surface ocean $\mathrm{CO}_{2}$ system in the northern North Atlantic using data from voluntary observing ships, Limnol. Oceanogr. Methods, 7, 109-118, 2009.

Olsson, K. and Anderson, L. G.: Input and biogeochemical transformation of dissolved carbon in the Siberian shelf seas, Cont. Shelf Res., 17(7), 819-833, 1997.

Orr, J. C., Fabry, V. J., Aumont, O., Bopp, L., Doney, S. C., et al.: Anthropogenic ocean acidification over the twenty-first century and its impact on calcifying organisms, Nature, 437, 681-686, doi:10.1038/nature04095, 2005.

Park, G. H., Kitack, L., Tischenko, P., Min, D. H., Warner, M. J., Talley, L. D., Kang, D. J., and Kim, K. R.: Large accumulation of anthropogenic $\mathrm{CO}_{2}$ in the East (Japan) Sea and its significant impact on carbonate chemistry, Global Biogeochem. Cy., 20(4), GB4013, doi:10.1029/2005GB002676, 2006.

Pocklington, R.: Arctic Rivers and their Discharges, Mitt. Geol.Paliont, Inst. Univ. Hamburg, SCOPE UNEP Sonderbd, 52, 35356, 1987.

Raven, J., Caldeira, K., Elderfield, H., et al.: Ocean acidification due to increasing atmospheric carbon dioxide, The Royal Society, Policy Document, London, UK, 2005.

Riebesell, U., Zondervan, I., Rost, B., Tortell, P. D., Zeebe, R., and Morel, F. M. M.: Reduced calcification of marine plankton in response to increased atmospheric $\mathrm{CO}_{2}$, Nature, 407, 364-367, 2000

Roy, R. N., Roy, L. N., Vogel, K. M., Porter-Moore, C., Pearson, T., Good, C. E., Millero, F. J., Campbell, D. M.: The dissociation constants of carbonic acid in seawater at salinities 5 to 45 and temperatures 0 to $46^{\circ} \mathrm{C}$, Mar. Chem., 44, 249-267, 1993.
Roy, R. N., Roy, L. N., Vogel, K. M., Porter-Moore, C., Pearson, T., Good, C. E., Millero, F. J., and Campbell, D. M.: Erratum for: The dissociation constants of carbonic acid in seawater at salinities 5-45 and temperatures $0-45^{\circ} \mathrm{C}$, Mar. Chem., 45, 337 pp., 1994.

Rudels, B., Jones, E. P., Schauer, U., and Eriksson, P.: Atlantic sources of the Arctic Ocean surface and halocline waters, Polar Res., 23, 181-208, 2004.

Rushdi, A. I., Pytkowicz, R. M., Suess, E., and Chen, C. T.: The effects of magnesium-to-calcium ratios in artificial seawater, at different ionic products, upon the induction time, and the mineralogy of calcium carbonate: a laboratory study, Geologische Rundschau, 81, 21571-21578, 1992.

Salisbury, J. E., Green, M., Hunt, C., and Campbell, J.: Coastal acidification by rivers: A threat to shellfish?, EOS T. Am.Geophys, Un., 89(50), 513-528, 2008.

Schlitzer, R.: Ocean Data View, http://www.awi-bremerhaven.de/ GEO/ODV, 2002

Shimada, K., Carmack, E. C., Hatakeyama, K., and Takizawa, T. Varieties of shallow temperature maximum waters in the western Canadian Basin of the Arctic Ocean, Geophys. Res. Lett., 28, 3441-3444, 2001.

Shirayama, Y. and Thornton, H.: Effect of increased atmospheric $\mathrm{CO}_{2}$ on shallow water marine benthos, J. Geophys. Res., 110, C09S08, doi:10.1029/2004JC002618, 2005.

Skirrow, G. and Whitfield, M.: The effect of increases in the atmospheric carbon dioxide content on the carbonate ion concentration of surface water at $25^{\circ} \mathrm{C}$, Limnol. Oceanogr., 20, 103-108, 1975.

Tyrrell, T., Schneider, B., Charalampopoulou, A., and Riebesell, U.: Coccolithophores and calcite saturation state in the Baltic and Black Seas, Biogeosciences, 5, 485-494, 2008, http://www.biogeosciences.net/5/485/2008/.

Walsh, J. J., McRoy, C. P., Coachman, L. K., Georing, J. J., Nihoul, J. J., Whitledge, T. E., Blackburn, T. H., Parker, P. L., Wirick, C. D., Shuert, P. G., Grebmeier, J. M., Springer, A. M., Tripp, R. D., Hansell, D. A., Djenidi, S., Deleersnijder, E., Henriksen, K., Lund, B. A., Andersen, P., Muller-Karger, F. E., and Dean, K.: Carbon and nitrogen recycling with the Bering/Chukchi Seas: source regions for organic matter effecting AOU demands of the Arctic Ocean, Progr. Oceanogr., 22, 277-359, 1989.

Wanninkhof, R., Lewis, E., Feely, R. A., and Millero, F. J.: The optimal carbonate dissociation constants for determining surface water $\mathrm{pCO}_{2}$ from alkalinity and inorganic carbon, Mar. Chem. 65, 291-201, 1999

Weingartner, T. J., Danielson, S. L., and Royer, T. C.: Freshwater variability and predictability in the Alaskan Coastal Current, Deep Sea Res. II, 52, 169-191, 2005.

Woodgate, R. A. and Aagaard, K.: Revising the Bering Strait freshwater flux into the Arctic Ocean, Geophys. Res. Lett., 32, L02602, doi:10.1029/2004GL021747, 2005.

Zeebe, R. E., Zachos, J. C., Caldeira, K., and Tyrrell, T. Carbon emissions and acidification, Science, 321, 5885, doi:10.1126/science.1159124, 2008. 